\title{
Forms of the State Support for Disabled Veterans in Tatarstan in Period of the Great Patriotic War
}

\author{
${ }^{1}$ Vasil T. Sakaev, ${ }^{2}$ Valery F. Telishev ${ }^{3}$ Ksenia A. Ermolaeva \\ ${ }^{1,2,3}$ Kazan Federal University, Institute of International Relations, History and Oriental Studies \\ Email: vasil.sakaev@gmail.com, Contact: +79272493705
}

\section{Received: 15th December 2017, Accepted: 20th December 2017, Published: 31st December 2017}

\begin{abstract}
Forms of the state support in days of the Great Patriotic War of the military personnel of Red Army who became disabled people were the research object in this article. The research was conducted on the basis of the published data, materials of media and archival sources. In work both the traditional, and special historical methods corresponding to character of the research purpose were used. The state support of disabled veterans was implemented in five forms, responsibility for which lay on party committees of the All-Union Communist Party ("Bolsheviks"), public authorities which are engaged in social security and also on public organizations (labor unions, "Komsomol") and military structures (military komissariat). Interaction of these actors had to promote more effective realization of social policy; however, it not always was fruitful. The received results correspond to conclusions of a number of the researchers who were also emphasizing the high importance of this direction of social policy for the Soviet government and it's, at the same time, low efficiency. Also results expand the available regional researches of social policy during the military period with new data. Results of a research can be useful to expansion of ideas of social history of war and about the nature of social policy of the Soviet state during the specified period.
\end{abstract}

Keywords: History, Great Patriotic War, Tatarstan, Social Policy, Disabled Veterans.

\section{Introduction}

The modern attention to social policy in the years of war is caused by the fact that position of disabled veterans remained beyond scientific interests of the Soviet historians. So, B. Fiziler specified that "being an undesirable research object, the subject of disabled veterans was studied not systematically, not to mention broad judgment of a problem in general" [1; 290].

Nevertheless, the number of the people who lost working capacity during war and needing social support was extremely high: no less than 2.6 million people $[2 ; 167]$. At the same time there are opinions, as this figure is significantly underestimated [1].

Taking into account the huge contingent of disabled veterans, it is necessary to light a role of the state in assistance to disabled veterans on the example of one of regions. Tatarstan where we will try to reveal the main forms of the state support of disabled veterans; its mechanisms can become such example, to estimate as far as they were effective. It is also important to consider specifics of interaction of various structures, such as party committees, public authorities of social security, public organizations and military structures, in the state support of disabled veterans.

\section{Methods}

The research was based on the analysis of acts, the secondary analysis of these published works, generalization of materials of newspapers of the military period, and also studying of unpublished sources from the Central state archive of historical and political documentation of the Republic of Tatarstan.

The analysis of these all-Russian researches, for example, of works E. N. Bol' [3], K.A Nasonova [4], I.S. Pisarenko [5] and regional researches Z.I. Gil'manova [7] and A.Sh. Kabirova [8] was carried out. In a foreign historiography these issues were touched in the demographic researches I.G. Dyadkin [9], B. Anderson and B. Silver [10], S. Adametz, A. Blum, S. Zakharov [11], S.G. Wheatcroft, R.W. Davies [12]. Also the works of foreign authors which are directly devoted to position of disabled people in the USSR, for example, of S.D. Phillips are of interest [13], S.P. Dunn, E. Dunn [14], B.Q. Madison [15] and J. Riordan [16].

\section{Results}

The realization of social policy concerning disabled veterans was enabled by the state at the different levels: "narcomats" (regional ministries), departments of social protection of districts (since 1943 regional departments of the state providing and the household device of families of soldiers), the commissions to destination pensions and allowances, and also the party committees exercising control. Activity of the industrial enterprises, collective farms, public organizations in this direction was completely accountable to party committees. An important role in social support of disabled veterans was played by military commissariats. In what forms this social support was carried out?

The analysis of sources allowed revealing five forms of assistance to disabled veterans:

Purpose of pensions and allowances, granting privileges. 
Provision of pensions was appointed depending on weight of mutilations. The status of the disabled person of the "I group" was received by the persons which completely lost working capacity and incapable to look after themselves, the "II group" lost ability to work, but capable to self-service, the "III group" - persons who kept ability to easy work only.

Departments of social security at which commissions of three officials for consideration in the three-day time of statements for purpose of pensions were created knew provision of pensions. The size of disability pension depended on a military rank. The average size of pension of the officer made 360 rubles, it is much less private [8; 372]. Of course, there were not enough these payments, for example, in the market in 1942-1943 the kilogram of butter cost not less than 425 rubles, kilogram of beef not less than 200 rubles, kilogram of potatoes - 20 rubles, kilogram of flour - 50 rubles, milk liter - 30 rubles $[17 ; 167]$.

The size of pension was influenced by earnings on the last place of work and disability degree.

It should be noted that at purpose of pensions in a number of the districts of Tatarstan refusals of the authorities of implementation of the relying payments under the pretext of lack of means took place $[17 ; 186-187]$. It is obvious that bodies of social protection were not ready to work with such numerous contingents needing providing. Besides, local authorities really had not resources for support of disabled veterans. Nevertheless, in 1941-1942 as pensions and grants in the republic 322 million rubles, in 1943 - 265.4 million rubles, in 1944 - 214 million rubles were paid [7; 274-275].

Granting privileges to disabled veterans happened according to the Resolution "SNK USSR" of 21.09.1945 No 2436. According to it, in villages from families of disabled people of the "I group" all agricultural shortages were written off; farms of disabled veterans of "I and II groups" at limited number able-bodied in a family and presence of minor dependents were exempted from obligatory deliveries of agricultural products and payment of an agricultural tax $[19 ; 110]$. Disabled veterans of the "I group" needed also release from a tuition fee of children [7; 271]. The same privileges were provided also to all disabled army officers of any group. Unfortunately, this important government decision actually appeared after the end of war and did not exert impact on position of disabled people during military time.

\section{Providing disabled veterans with housing.}

In the years of war issues of providing disabled people with housing were resolved only at the local level therefore not always their requirements were satisfied. So, in Kazan in 1943 the considerable number of unsatisfied requests of disabled veterans for provision of housing was revealed [20; 159-160].
After war granting housing to them happened according to the Resolution of 21.09.1945 No. 2436 and assumed allocation for these purposes in again built and restored houses of $10 \%$ of living space, preferential crediting of disabled veterans for acquisition or repair of housing (the loan from 5 to 10 thousand rubles with a repayment period from 5 to 10 years), and also release of building materials at low prices $[19 ; 110]$. Implementation of this resolution went extremely slowly, and even in 10 years after the end of war in Kazan still there were several hundreds of disabled veterans, poor housing $[20 ; 200]$.

\section{Material consumer services of disabled veterans.}

It assumed supply with food by delivery grain and food-cards.

Level of the state providing disabled veterans with food in the cities was higher, than in rural areas. In the cities shops of "Military Trade network" also functioned. Help to disabled people in the cities was given also by military commissariats. In too time disabled veterans in rural areas, as a rule, had subsidiary farms.

Industrial goods to disabled veterans were given on the basis of warrants which were appointed by bodies of social protection when obtaining the conclusion of the inspector about unsatisfactory material and household position of the disabled person, or on the basis of his personal statement with a request for granting clothes or footwear. However, the analysis of documents shows that in the years of war the issued warrants were not always executed [8; 161-162].

For material and household providing disabled veterans in Kazan it was open specialized shop and the dining room with two times food, and to disabled people of the "I group" products and lunches were delivered to the house [21].

It should be noted that material and household providing disabled officers differed to the best from supply of ordinary and non-commissioned officer's structure. Additional industrial goods were given by it, for example, disabled officers could receive in 1945 in addition 2 pairs of linen, a pair of shoes, a coat or a suit $[18 ; 39]$.

Checks of work of military trade in spring of 1945 revealed a number of problems. So, account of the served disabled veterans was not always kept, interruptions in supply with food took place, low was also a quality of public catering [22; 21].

Actually only after the end of war, the Resolution of 21.09.1945 No. 2436, distinguished additional funds of food and industrial goods for distribution from families of disabled veterans and mechanisms of their preferential providing with fuel were provided. 
Material consumer services of disabled veterans provided also check of observance of their living conditions and working conditions, including, through the Councils of assistance to disabled veterans created in the organizations. So, in the winter and spring of 1945 an inspection of the organization of work of disabled people at 103 enterprises of Kazan was carried out [19; 18].

\section{Creation of boarding schools for disabled veterans.}

According to some information, summer of 1944 in Russia 323 houses and 136 boarding schools for disabled people functioned [23; 29]. For 01.01.1946 48,276 people lived in nursing homes of war and in boarding schools $[23 ; 30]$.

Originally (until the end of 1943) norms of food supply of disabled veterans in boarding schools were defined by local authorities that caused distinctions in their providing in different regions.

Boarding schools for disabled people in Tatarstan had subsidiary farms that theoretically allowed providing wards with some food. The sizes of acreage depended on opportunities of these institutions, so, the cultivated area of the "Menzelinsky boarding school" for disabled veterans made 28 hectares [17; 183].

In too time, the inspections of a condition of nursing homes of war in Tatarstan which are carried out in 1944 revealed numerous problems in a sanitary condition of rooms, in food, medical and consumer services [17; 182-183].

\section{Rendering assistance to disabled veterans in employment.}

The decision on suitability of the disabled person to this or that profession was accepted by medical labor commissions of experts ("VTEK"). Though the quantity of "VTEK" in the years of war significantly increased [5; 80], nevertheless, their work was irregular, often there were no doctors of necessary specialization that affected results (inaccuracies when determining working capacity and group of disability were allowed). The state in the years of war stimulated disabled veterans to return to work with preservation of pension (the Resolution SNK USSR of 28.08.1942 made employment of disabled people of the "III group" an indispensable condition of receiving pension) and providing the right of primary employment [5]. The state sought to reduce as much as possible through regular medical examinations the number of disabled people "II and III groups", having transferred the first to the category is limited able-bodied, and the second - in the category completely able-bodied $[1 ; 291]$.

The Resolution SNK USSR of 06.05.1942 provided rendering assistance in employment of disabled veterans and their labor training, obliged local authorities to create the permanent commissions for the help, assistance and control in this question. However, apparently, this decision appeared insufficiently as the new Resolution obliging narcomats of social security of regions to arrange in three-month' time on production of all unemployed disabled veterans of the "III group" was issued 20.01.1943.

Since the end of 1942 in the country labor boarding schools for disabled veterans where they could master new professions [4] began to be created. It should be noted that in Tatarstan unsatisfactory execution of this decision was noted, so, the Tatar regional committee of the All-Union Communist Party ("Bolsheviks") of 08.01.1945 issued the resolution in which it pointed out the defects of this work.

Working ability of the former military personnel depended on character of mutilations. The smallest percent employed and retrained fell on disabled people of the heaviest "I group", the greatest - on disabled people of the "III group". In general, in 1945 in Tatarstan $84 \%$ of disabled veterans were employed [7; 272].

Work on retraining of disabled veterans to new professions was also based according to working capacity degree. Retraining was organized, as at the enterprises, and hospitals. For example, in one of military hospitals of Tatarstan training in professions of the shoemaker, tailor, accountant, etc. was organized [24]. However, in connection with objective difficulties in the years of war more than a half of disabled people were left without retraining and therefore, many of them were forced to be content with subsidiary work [1].

For social support of disabled veterans' practice of preservation of payment of pensions behind them, irrespective of the size of their salary, and working in collective farms - irrespective of the size of their income was established. Besides, were paid to disabled veterans of temporary disability benefit irrespective of an experience of continuous work.

\section{Discussion}

It should be noted that in a number of the previous works only 3 forms of the state help to disabled veterans were allocated: monetary payments, natural help (products, clothes, etc.), services and privileges [4; 66-67]. We managed to expand significantly ideas of the nature of the help of the state and to allocate five key forms of social policy concerning disabled veterans, and also to estimate overall performance of republican and local authorities in this direction.

Results of a research confirm conclusions of a number of authors who called care of disabled veterans the most important problem of the state in wartime. However, this care, unfortunately, often remained only at the level of declarations because of 
objective difficulties and limitation of resources of the Soviet state in the years of war. Our research supplements Z. I. Gil'manov [7] work as new data on the nature of social support and its forms. Substantially results of a research confirm opinion of A. Sh. Kabirova [8] who pointed to frequent discrepancy of the policy of the sensitive attitude towards needs of disabled veterans proclaimed the authorities, to the real situation.

In too time, it is difficult to agree with conclusions B. Fiziler which considered that the policy for disabled people was too cruel, and the state actually avoided them [1]. On an example Tatarastan we saw in general the attentive attitude towards veterans which of course could not always compensate a lack of resources. As for cruelty of social policy, it should be noted that the Soviet state, unfortunately, was brutal to all the citizens, and not just to disabled veterans only.

\section{Summary}

Thus, the state support of disabled veterans was carried out in five forms. Assistance to disabled veterans was proclaimed a priority task of social policy of the state. The help was carried out by party, Soviet, and public organizations, bodies of the state social protection and military structures. It had to increase efficiency of this direction of work, but the attracted archival sources sometimes testify to the return. The policy of the state on assistance to disabled veterans was far imperfect, and constantly demanded adjustment from the Soviet management.

\section{Conclusion}

Though, in general, the set research tasks were solved by us, but, in too time, a number of new questions within the studied subject was revealed. Unfortunately, during the research we did not manage to give the answer to a question of number and social composition of disabled veterans in the region. In the long term, it is also necessary to pay attention to the general and various in providing disabled veterans in rural and city areas, and also to consider a question of the level of medical care and social rehabilitation of disabled veterans in post-war years.

\section{Acknowledgements}

The work is performed according to the Russian Government Program of Competitive Growth of Kazan Federal University.

The article is prepared with financial support of the Russian Foundation for Basic Research (RFBR) and Government of the Republic of Tatarstan within the scientific project No. 17-11-16005/17OGON.

\section{References}

[1]Fiziler B. "Poor winners": disabled people of the Great Patriotic War in the Soviet Union", the Emergency ration, vol. 2-3(40-41), pp. 290-297, 2005.
[2]Isupov V. A. Demographic accidents and crises in Russia in the first half of the 20th century: historical and demographic sketches. - Novosibirsk: Siberian chronograph, 2000.

[3]Bol' E. N. "Provision of pensions of disabled people of the Great Patriotic War in military and first post-war years", Military and historical magazine, vol. 4, pp. 25-30, 2009.

[4]Nasonov K. A. "Social security of the military personnel of Red Army in days of the Great Patriotic War: essence, contents and modern value", Bulletin of Military university. Vol. 3(23), pp. 65-70, 2010.

[5]Pisarenko I. S. "The Soviet legislation on employment of disabled people during the Great Patriotic War", Urgent problems of humanitarian and natural sciences, Vol. 7-1, pp. 78-85, 2014.

[6]Isupov V. "Demographic catastrophes in Russia", Problem of Economic transition, Vol. 37(2), pp. 613, 1994.

[7]Gil'manov Z. I. Tataria in the Great Patriotic War (1941-1945). - Kazan: Tatar book publishing house, 1977.

[8]Kabirova ASh. Tatarstan in the years of military tests (1941-1945). - Kazan: Yaz publishing house, 2015.

[9]Dyadkin I.G. Unnatural Deaths in the USSR, 1928-1954. New Brunswick; London, 1983.

[10] Anderson B., Silver B. "Demographic analysis and population catastrophes in the USSR", Slavic Review, Vol. 44, No 3, pp. 517-536, 1985.

[11] Adametz S., Blum A., Zakharov S. Disparites et variabilites des catastrophes demographiques en URSS. Paris, 1994.

[12] Wheatcroft S.G., Davies R.W. In the Mirror of the Soviet Statistics/in the Davies R.W., Harrison M., Wheatcroft S.G. (eds.) The Economic Transformation of the Soviet Union, 1913-1945. Cambridge, 1994.

[13] Phillips S.D. "There are no Invalids in the USSR": A missing Soviet chapter in the Disability Histiry", Disability Studies Quarterly, Vol. 29, No 3, pp. 1-35, 2009

[14] Dunn, S.P. and E. Dunn. Everyday Life of people with disabilities in the USSR. In People with Disabilities in the Soviet Union: Past and Present, Theory and Practice. William O. McCagg and Lewis Siegelbaum, eds. Pp. 199-234. Pittsburgh: University of Pittsburgh Press. 1989.

[15] Madison, Bernice Q. Social Welfare in the Soviet Union. Stanford: Stanford University Press. 1968. 
[16] Riordan, Jim, ed. Soviet Education: The Gifted and the Handicapped. London and New York: Routledge. 1988.

[17] Tatarstan in days of the Great Patriotic War: pages of social history: Collection of documents and materials. - Kazan: GAU at KM of RT, 2011.

[18] TsGA IPD RT, t. 15, 5, 1667, 108.

[19] TsGA IPD RT, t. 15, 5, 1857, 178.

[20] History of Kazan in documents and materials: 20th century. - Kazan: Magarif, 2004.

[21] Red Tataria. - 1944. - September 14.

[22] TsGA IPD RT, t. 15, 5, 1859, 114.

[23] Zinich M. Z. Everyday life of military hard times. 1941-1945. Issue 2. - M.: "The Russian press service", 1994.

[24] Red Tataria. - 1941. - December 25. 